Magdalena Paluszkiewicz

Uniwersytet Łódzki

\title{
POROZUMIENIA, UMOWY ORAZ ZLECENIE USŁUG LUB INSTRUMENTÓW RYNKU PRACY NA GRUNCIE USTAWY O PROMOCJI ZATRUDNIENIA I INSTYTUCJACH RYNKU PRACY ${ }^{1}$ - KILKA UWAG DE LEGE FERENDA
}

Powołany w tytule akt prawny obfituje w różnorodne i wieloznaczne określenia dotyczące form prawnych działań podejmowanych przez podmioty funkcjonujące na rynku pracy, co skłoniło autorkę do sformułowania kilku zasadniczych uwag $\mathrm{w}$ tej materii. Poruszany tutaj problem zdaje się mieć istotne znaczenie praktyczne, zwłaszcza dla podmiotów administrujących, realizujących zadania określone we wskazanej ustawie, w szczególności zaś w zakresie sposobu zawierania, realizacji, jak również środków prawnych związanych z wadliwym wykonaniem, bądź niewykonaniem umów, porozumień i zleceń. W artykule tym ze względu na jego ograniczony zakres, naświetlono tylko znacznie szerszy problem braku precyzji tekstu ustawy o promocji zatrudnienia.

Ustawa o promocji zatrudnienia w licznych przepisach ${ }^{2}$ posługuje się pojęciem ,porozumienia”, nigdzie jednak tej kategorii nie definiu-

${ }^{1}$ Tekst jedn. Dz. U. z 2008 r. Nr 69, poz. 415 ze zm., dalej: ustawa o promocji zatrudnienia.

${ }^{2}$ Na przykład - art. 2 ust. 2 , art. 4 ust. 2, art. 8 ust. 8 pkt 9, art. 9a ust. 3 , art. 13, art. 23 ust. 4 a, art. 50 ust. 3 , art. 67 ust. 3 , art. 70 ust. 4 pkt 3, art. 73 a ust. 2 , art. 75 ust. 1 pkt 2 , art. 90 ust. 8 , art. 106 a ust. 2 pkt 1 . 
jąc. Zgodnie ze słownikiem języka polskiego porozumienie oznacza zgodę na coś, wzajemne zrozumienie lub umowę, układ ${ }^{3}$. Teoretycy prawa owo „wzajemne zrozumienie” określają mianem konsensu ${ }^{4}$, odżegnując się jednak od posługiwania się terminem „porozumienie” jako zbyt ogólnym, odnoszącym się bowiem do pomyślnego etapu procesu komunikowania się ludzi między sobą ${ }^{5}$. Jednakowoż konsens jako zgodne oświadczenie woli stron jest z kolei elementem koniecznym umowy ${ }^{6}$. Zaciera się wobec powyższego granica pomiędzy porozumieniem a umowa, bowiem porozumienie stanowi jeden z jej elementów. Dowodem na to, iż trudno odróżnić te dwa terminy może być definicja porozumienia z ustawy o ochronie konkurencji i konsumentów, w świetle której rozumie się przez nie: a) umowy zawierane między przedsiębiorcami, między związkami przedsiębiorców oraz między przedsiębiorcami i ich związkami albo niektóre postanowienia tych umów, b) uzgodnienia dokonane w jakiejkolwiek formie przez dwóch lub więcej przedsiębiorców lub ich związki ${ }^{7}$. Można próbować bronić poglądu, że porozumienie oznacza zgodę jego stron co do jakiejś pojedynczej, konkretnej kwestii i to niekoniecznie wywołujące skutki w sferze prawnej ${ }^{8}$, natomiast umowa oznacza zgodę jej stron na zaistnienie kompleksowej sytuacji prawnej. Podział ten nie jest jednak ani precyzyjny, ani rozłączny bowiem w praktyce znajdziemy pewnie porozumienia obejmujące złożone kwestie, jak i umowy

${ }^{3}$ Internetowy słownik języka polskiego PWN, http://sjp.pwn.pl/lista.php?co= porozumienie, dostęp 23 grudnia $2010 \mathrm{r}$.

4 Tak Z. Radwański, Teoria umów ${ }^{7}$, Warszawa 1977, s. 67; TenżE: Prawo cywilneczęść ogólna, Warszawa 2004, s. 284.

5 TenżE, Teoria, cit., s. 67.

${ }^{6}$ Tamże, s. 62; Z. RAdwańsKi, A. OlejniczaK, Zobowiqzania - część ogólna ${ }^{7}$, Warszawa 2006, s. 117; W. CzAchóRsKi, Zobowiqzania7, Warszawa 1994, s. 129; Prawo cywilne, red. S. GrzyBowski, Warszawa 1981, s. 66.

7 Art. 4 pkt 5 ustawy z dnia 16 lutego 2007 r. o ochronie konkurencji i konsumentów, Dz.U. Nr 50, poz. 331 ze zm.

8 Wskazuje na to, moim zdaniem, regulacja art. $761^{5} \S 5$ k.c., w którym mowa jest o nieosiągnięciu porozumienia co do wyboru biegłego rewidenta, art. $290 \S 3$ k.c., w którym mowa o braku porozumienia co do sposobu wykonywania służebności. 
dotyczące jednego konkretnego zagadnienia. Ukazuje to jedynie, jak istotne konsekwencje praktyczne ma, niespełniony niestety w rozpatrywanym przypadku, postulat precyzji językowej tekstów prawnych. Trzeba jednak założyć, że skoro racjonalny ustawodawca w tej samej ustawie, w jednym przypadku przewiduje formę umowy dla podejmowanych przez strony działań, $w$ innym zaś formę porozumienia, to nie są one tożsame. Próbując usystematyzować powyższy wywód można więc stwierdzić, że porozumienie oznacza ustalenie wspólnego, zgodnego stanowiska $\mathrm{w}$ danej sprawie, a także pomyślny etap procesu komunikowania się (porozumienie w znaczeniu potocznym). Termin ten można także utożsamiać ze zgodną wolą stron dotyczącą wywołania bądź unicestwienia skutków czynności prawnej (porozumienia zbliżone charakterem do umów cywilnoprawnych, porozumienia międzynarodowe, porozumienia administracyjne, porozumienie dotyczace ustania stosunku prawnego). W polskim porządku prawnym porozumienie występuje zarówno $\mathrm{w}$ znaczeniu potocznym ${ }^{9}$, jak również w znaczeniu czynności prawnej - chodzi tu głównie o porozumienie zbliżone de facto do umowy cywilnoprawnej, porozumienia międzynarodowe ${ }^{10} \mathrm{i}$ administracyjne.

Przechodząc do rozważań nad konkretnymi rozwiązaniami przyjętymi w ustawie o promocji zatrudnienia należy zauważyć, że mamy w niej do czynienia z różnorodnymi porozumieniami. Przykłady porozumienia jako zgody znaleźć można w art. 4 ust. 2, art. 8 ust. 8 pkt 9 , art. 90 ust. 8, gdzie mowa jest o zgodnym współdziałaniu organów administracji w wydawaniu przepisów wykonawczych. W powołanej ustawie mowa jest również o porozumieniach jako czynnościach prawnych zbliżonych, czy też tożsamych z umową cywilnoprawną - chodzi tu o porozumienie wolontariusza z korzystającym, zawierane na podstawie przepisów o działalności pożytku publicznego i wolontariacie, o czym mowa w art. 2 ust. 2 ustawy o promocji zatrudnienia, a także o porozumienie pracodawców w sprawie utworzenia funduszu szkole-

${ }^{9}$ Np. art. $761^{5} \S 5$ k.c., art. $567 \S 1$ k.c.

${ }^{10} \mathrm{~Np}$. Europejskie Porozumienie o Wolnym Handlu (EFTA). 
niowego na podstawie art. 67 ust. 3. W art. 90a ust. 3 pkt 2 mowa jest zaś o porozumieniach międzynarodowych w zakresie zatrudnienia.

Istotne wattpliwości powstają natomiast w odniesieniu do charakteru porozumienia zawieranego przez powiaty na gruncie art. 9a ust. 3 ustawy o promocji zatrudnienia. Ustawodawca przewiduje obowiązek $^{11}$ współpracy powiatów, która polega na współfinansowaniu realizowanych na ich rzecz zadań. Cywilnoprawna zasada swobody umów przewiduje możliwość nieskrępowanego doboru kontrahenta i wolność $\mathrm{w}$ zakresie decyzji o nawiązaniu umowy ${ }^{12}$. W omawianym przypadku mamy do czynienia z obowiązkiem współpracy oraz z konkretnym wymogiem, by stronami porozumienia były powiaty, czyli jednostki samorządu terytorialnego. Zasadnicze wątpliwości dotyczą jednak celu zawieranego porozumienia, któremu trudno przypisać charakter gospodarczy, typowy dla umów prawa prywatnego. Ma ono bowiem określać zasady wykonywania i finansowania zadań powiatowego urzędu pracy (tzw. powiat prowadzący) dla wszystkich powiatów (dotujących) biorących udział w porozumieniu. Zadania powiatowych urzędów pracy należą do kategorii zadań publicznych, przez które należy rozumieć zadania związane z zaspokajaniem zbiorowych potrzeb ludności ${ }^{13}$, wymienione chociażby w ustawach ustrojowych samorządu terytorialnego ${ }^{14}$ czy w ustawie o administracji rządowej w wojewódz-

${ }^{11}$ Na co wskazuja, moim zdaniem, użyte sformułowania ,jest współfinansowany" w ustępie 1 art. 9a, oraz ,zawierają” w ustępie 3 tego samego artykułu. Tak też J. STRZELECKA, Informacja dotyczaca projektu ustawy o zmianie ustawy o promocji zatrudnienia $i$ instytucjach rynku pracy oraz o zmianie niektórych innych ustaw (druk 3881), s. 2, http://orka.sejm.gov.pl/rexdomk4.nsf/Opwsdr?OpenForm\&3881, dostęp: 22 grudnia $2010 \mathrm{r}$.

12 Z. RadWAŃski, Teoria, cit., s. 99 i n.

${ }_{13}$ M. Koroblowski, Kilka uwag na temat porozumień zawieranych przez jednostki samorzqdu terytorialnego oraz przez te podmioty $i$ organy administracji rzqdowej, «Samorząd Terytorialny» 7-8/2004, s. 36; P. Brzezicka, Porozumienia administracyjne - problemy węzłowe, «PiP»65.6/2000, s. 46 i 47.

${ }^{14}$ Art. 7 ust. 1 ustawy z dnia 8 marca 1990 r. o samorządzie gminnym (tekst jedn. Dz.U. z 2001 r. Nr 142, poz. 1591 ze zm.), art. 4 ust. 1 ustawy z dnia 5 czerwca 1998 r. o samorządzie powiatowym (tekst jedn. Dz.U. z 2001 r. Nr 142, poz. 1592 ze zm.), 
twie ${ }^{15}$. Powyższe cechy wskazują, moim zdaniem, że mamy w tym wypadku do czynienia z porozumieniem administracyjnym określanym jako prawna, niewładcza forma działania administracji ${ }^{16}$. Stronami tego porozumienia sa jednostka przejmująca zadania, a z drugiej jednostka powierzająca zadania ${ }^{17}$. Obie te jednostki (co najmniej jedna ${ }^{18}$ ) muszą być podmiotami, na których spoczywają ustawowe obowiązki wykonywania administracji publicznej ${ }^{19}$, zatem wydaje się, że powiaty realizując zadania nałożone przez ustawę spełniają tenże wymóg. Ponadto, fundamentalną cechą porozumienia administracyjnego jest współdziałanie przy wykonywaniu zadań administracji publicznej ${ }^{20}$. Jak wskazuje się w literaturze prawa administracyjnego, w wyniku zawarcia

art. 14 ust. 1 ustawy z dnia 5 czerwca 1998 r. o samorządzie województwa (tekst jedn. Dz.U. z 2001 r. Nr 142, poz. 1590 ze zm.).

15 Ustawa z dnia 23 stycznia 2009 r. o wojewodzie i administracji rządowej w województwie (Dz.U. Nr 31, poz. 206), art. 20 ust. 1.

16 B. Dolnicki, R. Cybulska, Nowe dwustronne formy działania administracji publicznej-zagadnienia wybrane, [w:] Koncepcja systemu prawa administracyjnego, Zjazd Katedr Prawa Administracyjnego i Postęowania Administracyjnego Zakopane 24-27 września 2006 r., red. J. ZimMERMAnN, Wrocław 2007, s. 456.

17 J. Boć, Prawo administracyjne, Wrocław 2001, s. 346, podaję za: B. Dolnickim i R. Cybulską, op. cit., s. 457.

${ }^{18} \mathrm{~W}$ kwestii tego, czy obie strony porozumienia muszą być jednostkami realizującymi zadania publiczne nie ma w doktrynie prawa administracyjnego jednolitego stanowiska. Duże grono zwolenników ma także pogląd, w świetle którego dla zakwalifikowania danej czynności prawnej jako porozumienie administracyjne wystarczy, gdy tylko jedna strona realizuje ustawowo nałożone zadania publiczne, tak np., Z. Cieślak, Prawo administracyjne, Warszawa 1996, s. 200; Z. SzRENIAwski, Prawo administracyjne. Część ogólna, Lublin 1994, s. 110, podaję za: B. Dolnickim, R. Cybulska, op. cit., s. 460, przyp. 21.

19 D. KiJowski, Umowy $w$ administracji publicznej, [w:] Podmioty administracji publicznej i prawne formy ich działania. Studia i materiaty z konferencji naukowej poświęconej jubileuszowi 80-tych urodzin Profesora Eugeniusza Ochendowskiego, Torun 2005, s. 299; Prawo administracyjne. Pojęcia, instytucje, zasady $w$ teorii i orzecznictwie ${ }^{2}$, red. M. Stahl, Warszawa 2002, s. 367; B. Dolnicki, R. Cybulska, op. cit., s. 457.

${ }^{20}$ P. Brzezicka, op. cit., s. 46; B. Dolnicki, R. Cybulska, op. cit., s. 458; D. KiJowsKi, op. cit., s. 299; M. STAHL (red.), op. cit., s. 367. 
porozumienia jednostka wykonująca zadania objęte porozumieniem przejmuje prawa i obowiązki pozostałych jednostek uczestniczących w porozumieniu, a jednostki te mają obowiązek partycypować w kosztach realizacji tego zadania ${ }^{21}$. Partycypacja finansowa powiatów dotujących polega na przekazywaniu powiatowi prowadzącemu urząd pracy dotacji celowych na wydatki bieżące. Powyższe ustalenia rodzą dalsze konsekwencje w postaci konieczności wskazania organu właściwego do rozstrzygania sporów powstałych na tle porozumień. Chodzi w głównej mierze o niewykonywanie bądź niewłaściwe wykonywanie porozumienia przez jedną ze stron. Wyraźną regulację prawną w tym zakresie zawiera art. 8 ust. 2 b ustawy o samorządzie gminnym ${ }^{22}$, ale tylko w odniesieniu do porozumień zawieranych między gminami i o ile spory z nich wynikłe mają charakter majątkowy. Wówczas właściwy do załatwienia sprawy jest sąd powszechny. Wydaje się, że w pozostałym zakresie kontrola nad prawidłowością realizacji zadań publicznych i wydatkowania środków Funduszu Pracy sprawowana jest $\mathrm{w}$ trybie nadzoru wojewody na podstawie art. 10 ust. 1 pkt 3 i 5 ustawy o promocji zatrudnienia. Rozstrzygnięcie nadzorcze wojewody podlega zaś zaskarżeniu z powodu niezgodności z prawem do sądu administracyjnego na podstawie art. 85 ust. 2 ustawy o samorządzie powiatowym.

Podobny charakter prawny maja, w mojej ocenie, porozumienia zawierane na podstawie art. 73a ust. 2 i 106a ust. 2 pkt 1 ustawy o promocji zatrudnienia, przy czym nie ma w tych przypadkach jasności co do trybu rozstrzygania sporów powstałych na ich tle. Można próbować bronić tezy, iż podlegają one nadzorowi wojewody na postawie art. 10 ust. 1 pkt 5, w którym mowa o sprawowaniu nadzoru nad realizacją zadań wykonywanych przez inne podmioty w zakresie kontroli realizacji zadań (w tym także przekazywanych w drodze porozumień), wynikających z ustawy. Jak się wydaje, podstawą do zaskarżenia decyzji nadzorczej do sądu administracyjnego jest art. $3 \S 2$ pkt 7 ustawy z dnia 30 sierpnia 2002 r. Prawo o postępowaniu przed sądami administra-

${ }^{21}$ D. KiJowsKi, op. cit., s. 299.

${ }^{22}$ Ustawa z dnia 8 marca 1990 r., tekst jedn. Dz.U. z 2001 r. Nr 142, poz. 1591 ze zm. 
cyjnymi ${ }^{23}$. Kończąc rozważania dotyczące porozumień występujących w ustawie trzeba zwrócić jeszcze uwagę na art. 75 ust. 1 pkt 2, w którym mowa o porozumieniu stron jako formie rozwiązania umowy o prace.

Kolejną prawną formą działań podejmowanych przez podmioty funkcjonujące w oparciu o ustawę o promocji zatrudnienia jest umowa. Zgodnie z ogólnie akceptowanym, wobec braku definicji ustawowej, poglądem jest to czynność prawna, składająca się z dwóch elementów koniecznych - uczestnictwa co najmniej dwóch stron i zgodnego oświadczenia woli tychże stron ${ }^{24}$. Wskazuje się generalnie, że w działaniach podejmowanych przez administrację publiczną zastosowanie mają dwa rodzaje umów - umowy cywilnoprawne i tzw. umowy publicznoprawne ${ }^{25}$, zwane też administracyjnymi ${ }^{26}$. Na gruncie ustawy o promocji zatrudnienia mamy do czynienia $\mathrm{z}$ umowami, których charakter prawny nie wzbudza zasadniczych wątpliwości - mowa o umowach służących świadczeniu pracy wymienionych w art. 2 ust. 1 pkt 11, art. 88 pkt 1, art. 104 b ust.1, oraz o umowach stanowiących źródło prawa międzynarodowego w art. $18 \mathrm{c}$ ust. 1 pkt 4 , art. 84, art. 87 ust. 2 pkt 9, art. 106 b ust. 2 i 3. Sa jednak umowy, co do których charakteru prawnego nie można już wypowiedzieć się tak jednoznacznie. Watpliwości wywołuje bowiem umowa pożyczki zawierana na podstawie art. 42 ust. 1 przez starostę i bezrobotnego w celu sfinanso-

${ }^{23}$ Dz. U. nr 153, poz. 1270 ze. zm.; dalej: poppsa.

${ }^{24}$ Z. RAdWAŃski, Teoria, cit., s. 62.

25 D. KıJowski, op. cit., s. 281. Często przedstawiciele doktryny prawa administracyjnego posługują się pojęciem „umowa publicznoprawna”. Wskazuje się jednak, że mimo mogących w praktyce występować pewnych różnic co do zakresu podmiotowego umowy publicznoprawnej i umowy administracyjnej, pojęcia te należy uznać za tożsame - A. PANAsıUK, Umowa publicznoprawna (próba definicji), »Państwo i Prawo« 2/2008, s. 18; tak też B. Dolnicki, R. CyBulsKA, op. cit., s. 456.

${ }^{26}$ J. LemańsKa, Umowa administracyjna a umowa cywilnoprawna, [w:] Instytucje współczesnego prawa administracyjnego, Księga jubileuszowa prof. J. Filipka, Wydawnictwo Uniwersytetu Jagiellońskiego, Kraków 2001, s. 421; K. ZIEMSKI, Alternatywy dla aktu administracyjnego, [w:] Koncepcja systemu prawa administracyjnego, cit., s. 422; B. Dolnicki, R. Cybulska, op. cit., s. 461 i nast.; M. Stahl red., op. cit., s. 466. 
wania do określonej kwoty kosztów jego szkolenia, które umożliwi mu podjęcie lub utrzymanie zatrudnienia lub innej pracy zarobkowej. Wydaje się, że nie można tej umowy zakwalifikować jako umowy pożyczki regulowanej art. 720 i nast. k.c. Stroną jej jest bowiem starosta dysponujący środkami publicznymi - finansowanie pożyczki odbywa się z Funduszu Pracy na podstawie art. 108 ust. 1 pkt 11 ustawy o promocji zatrudnienia. Z kolei charakter środków finansowych przesądza o szczególnych zasadach rządzących wykonywaniem tejże umowy. Chodzi tu przede wszystkim o ustawowo określony cel, w jakim pożyczki się udziela, limitowaną wysokość przekazywanych środków (art. 42 ust. 1), ostateczny termin spłaty (art. 42 ust. 2) oraz sankcje związane z niecelowym wykorzystaniem pożyczki, nieterminową spłatą bądź niepodjęciem albo nieukończeniem szkolenia (art. 42 ust. 3). Jak wynika z powyższego, bezrobotny w umowie nie tylko zobowiązuje się zwrócić określoną kwotę w wyznaczonym terminie, ale również, a w zasadzie przede wszystkim, podjać i ukończyć szkolenie, które umożliwi mu zatrudnienie lub wykonywanie innej pracy zarobkowej. Ponadto, bardzo istotne elementy treści tej umowy są niezależne od woli jej stron, bowiem wynikają wprost z ustawowych przepisów, które zasadniczo nie mają dyspozytywnego charakteru. W konkluzji nasuwa się więc wniosek, iż nie jest to umowa pożyczki, za pomocą której strony realizują własne interesy gospodarcze, ale umowa, której przedmiotem jest realizacja zadania publicznego, jakim jest w tym przypadku aktywizacja zawodowa bezrobotnego. Nie można w konsekwencji uniknąć odpowiedzi na pytanie o charakter prawny tejże umowy. Ze względu na cel, do którego realizacji ma prowadzić zawarta umowa, a jest nim wykonanie zadania publicznego $^{27}$, należy uznać, że mamy w tym przypadku do czynienia z umową administracyjną.

${ }^{27}$ Na podstawie art. 9 ust. 1 pkt 2 ustawy o promocji zatrudnienia samorząd powiatu realizuje zadania $\mathrm{w}$ zakresie polityki rynku pracy polegające na gospodarowaniu środkami finansowymi na realizację zadań z zakresu aktywizacji lokalnego rynku pracy. Natomiast zgodnie z art. 4 ust. 1 pkt 17 ustawy o samorządzie powiatu, powiat wykonuje określone ustawami zadania publiczne o charakterze ponadgminnym w zakresie przeciwdziałania bezrobociu i aktywizacji lokalnego rynku pracy. 
Wobec braku legalnej definicji ${ }^{28}$ jako podstawową cechę pozwalającą odróżnić umowę administracyjną od umowy cywilnoprawnej wskazuje się w literaturze prawa administracyjnego bezpośrednie wywoływanie skutków w sferze prawa administracyjnego ${ }^{29}$, lub publiczny charakter zadania, dla którego realizacji umowa została zawar$\mathrm{ta}^{30}$. Przez owe skutki należy rozumieć określenie praw i obowiązków jednostki zawierającej umowę wobec organu realizującego $\mathrm{w}$ formie władczej $^{31}$ zadanie z zakresu administracji publicznej32. Jeżeli zaś realizacja zadania przebiega przy użyciu form niewładczych (w szczególności umownych), wówczas jako podstawowe kryterium należy przyjać charakter zadania ${ }^{33}$. Ustalenie, że jest to zadanie z zakresu administracji publicznej będzie świadczyć o administracyjnym charakterze zawartej umowy. Kolejną cechą przemawiającą za uznaniem, że w art. 42 ustawy o promocji zatrudnienia mamy do czynienia $z$ umową administracyjną jest to, że jako jej strona występuje podmiot publiczny w osobie starosty ${ }^{34}$. Ponadto, jak zostało to już zauważone wcześniej, strony tejże umowy mają ograniczoną możliwość kształtowania jej treści, co jest także typową cechą umowy administracyjnej ${ }^{35}$. Podobny

28 Ciężar definiowania umowy administracyjnej spada na doktrynę i judykaturę.

29 D. KiJowski, op. cit., s. 296.

30 Tamże, s. 296; J. LemańsKA, op. cit., s. 424.

31 Formy władcze to takie, gdy administracja przy załatwianiu sprawy używa władztwa administracyjnego - M. STAHL (red.), op. cit., s. 351.

32 D. KuJowsKi, op. cit., s. 296.

33 Tamże.

34 Szerzej na temat występowania podmiotu publicznego jako strony w umowie: A. Panasiuk, op. cit., s. 30; D. KiJowski, op. cit., s. 296. Istnieje pewna rozbieżność poglądów co do sytuacji, w której obie strony czynności prawnej są podmiotami publicznymi (organami administracyjnymi) - niektórzy stoją na stanowisku, iż mamy wówczas do czynienia z umową administracyjną - tak: A. PANASIUK, op. cit., s. 30, inni natomiast opowiadają się za porozumieniem administracyjnym - tak: J. LEMAŃSKA, op . cit., s. 425; B. Dolnicki, R. Cybulska, op. cit., s. 464; D. KiJowski, op. cit., s. 299.

35 J. LEMAŃSKA, op. cit., s. 423, autorka wskazuje, że umowy te kształtem zbliżone są do umów przystąpienia (adhezyjnych). 
charakter prawny maja, w moim przekonaniu, umowy o których mowa w art. 42a i 46 ustawy.

Wykorzystywanie umów cywilnych i administracyjnych w ramach tzw. niewładczych form działania ${ }^{36}$ przez administrację pozostaje w ścisłym związku ze zjawiskiem prywatyzacji zadań publicznych. Jest ono definiowane jako proces polegający najczęściej na przekazywaniu podmiotom prywatnym zadań publicznych prawnie przypisanych administracji rządowej i samorządowi terytorialnemu ${ }^{37}$. Mianem prywatyzacji zadań publicznych określa się także proces poszukiwania sposobów rozwiązywania trudności związanych z realizacją rozbudowanych zadań administracji publicznej, w szczególności zaś sposobów zmniejszania kosztów wykonawstwa, zwiększania efektywności działań i tworzenia alternatywnych sposobów zaspokajania potrzeb ludności ${ }^{38}$. Jak wskazuje się w literaturze prawa administracyjnego umowy prywatnoprawne są wykorzystywane w trzech płaszczyznach działań administracji: (1) bezpośrednie wykonywanie zadań tzw. administracji świadczącej ${ }^{39}$, (2) tworzenie i utrzymywanie urządzeń użyteczności publicznej lub urządzeń i przedmiotów niezbędnych do funkcjonowania urzędów i instytucji administrujących, oraz (3) działalność fiskalna ${ }^{40}$. Mimo ogromnej elastyczności jaką stwarzają umowy cywilnoprawne w zakresie realizacji różnych celów gospodarczych, istnieje sfera nie-

36 M. STAHL (red.), op. cit., s. 218 i 351, chodzi tu w szczególności o zastępowanie decyzji administracyjnej umowami cywilnoprawnymi.

37 A. BŁAś, Formy działania administracji $w$ warunkach prywatyzacji zadań publicznych, [w:] Administracja i prawo administracyjne u progu trzeciego tysiaclecia, Materiały konferencji naukowej Katedr Prawa i Postępowania Administracyjnego, Łódź 2000, s. 23; A. WiKTorowsKa, Kierunki zmian w teorii prawnych form działania administracji, [w:] Koncepcja systemu prawa administracyjnego, cit., s. 380.

38 M. STAHL (red.), op. cit., s. 217.

39 Administracja działająca zasadniczo w formach niewładczych, zaspokajająca podstawowe potrzeby bytowe obywateli, organizująca usługi publiczne - M. STAHL (red.), op. cit., s. 18 i 19.

40 Tak np. D. KIJOwsKi, op. cit., s. 283; H. KNysiaK-MolcZYK, Umowa cywilnoprawna jako forma działania organów administracji publicznej, [w:] Koncepcja systemu prawa administracyjnego, cit., s. 495; J. LEMAŃSKA, op. cit., s. 423. 
nadająca się do uregulowania prawem prywatnym ${ }^{41}$. Chodzi mianowicie o realizację zadań publicznych, co najczęściej następuje w formach umów administracyjnych i porozumień administracyjnych ${ }^{42}$.

W tym kontekście bliżej należy przyjrzeć się instytucji zlecenia realizacji usług rynku pracy, uregulowanej w art. 24 ustawy o promocji zatrudnienia $^{43}$. Marszałek województwa albo starosta mogą bowiem zlecić realizację usługi rynku pracy podmiotom wskazanym w art. 24 ust. 1. Powstaje pytanie o charakter prawny tego zlecenia. Do dnia 12 marca 2010 r. podstawą prawną była w tej mierze verba legis umowa o realizację usługi rynku pracy (por. uchylony art. 3244). Po tej dacie zlecanie usług lub instrumentów rynku pracy następuje, zgodnie $\mathrm{z}$ art. 24 ust. 2 ustawy o promocji zatrudnienia, na podstawie ustawy z dnia 24 kwietnia 2003 r. o działalności pożytku publicznego i o wolontariacie $^{45}$ lub ustawy z dnia 29 stycznia 2004 r. Prawo zamówień publicznych $^{46}$.

Ustawa o działalności pożytku publicznego i o wolontariacie ${ }^{47}$ przewiduje w art. 11-19 zasady prowadzenia działalności pożytku publicznego na podstawie zlecenia realizacji zadań publicznych. Z punktu widzenia problematyki poruszanej w niniejszym artykule najistotniejsze znaczenie ma zlecanie zadań określonych w art. 4 ust. 1 pkt 8 tej ustawy - czyli w zakresie promocji zatrudnienia i aktywizacji zawodo-

41 Podobnie D. KJJowsKi, op. cit., s. 281.

42 Tamże.

43 Uwage zwraca niekonsekwencja ustawodawcy - w art. 24 ust. 1 mowa jest o zlecaniu wyłącznie usług rynku pracy, natomiast w ust. 3 tego samego artykułu mowa jest już o ,zlecaniu usług rynku pracy lub usług i instrumentów rynku pracy”. Zredagowanie tych przepisów w formie jednego artykułu pozwala przyjąć, że marszałek województwa lub starosta zgodnie z art. 24 ust. 1 mogą zlecić realizację usług rynku pracy lub usług i instrumentów rynku pracy wskazanym w tym przepisie podmiotom.

${ }^{44}$ Art. 13 ustawy z dnia 22 stycznia 2010 r. o zmianie ustawy o działalności pożytku publicznego i o wolontariacie oraz niektórych innych ustaw, Dz.U. Nr 28, poz. 146.

45 Tekst jedn. Dz.U. z 2010 r. Nr 234, poz. 1536.

46 Tekst jedn. Dz.U. z 2010 r. Nr 113, poz. 759 ze zm.

${ }^{47}$ Dalej: ustawa o działalności pożytku publicznego. 
wej osób pozostających bez pracy i zagrożonych zwolnieniem. W tak ogólnie określonym zadaniu mieści się zatem formuła zlecania usług lub instrumentów rynku pracy z art. 24 ust. 2 ustawy o promocji zatrudnienia. Procedura zlecania rozpoczyna się od wyłonienia w drodze otwartego konkursu ofert organizacji pozarządowej, spółdzielni socjalnej, stowarzyszenia jednostek samorządu terytorialnego lub innych podmiotów wskazanych w art. 3 ust. 3 ustawy o działalności pożytku publicznego. Krąg podmiotów, którym zleca się w tym trybie realizację usługi lub usługi i instrumentu rynku pracy jest jednak dodatkowo ograniczony. Ustawa o działalności pożytku publicznego w art. 3 ust. 4 przewiduje, że omawianego trybu zlecania nie stosuje się min. do związków zawodowych i organizacji pracodawców, a podmioty te zostały wskazane w art. 24 ust. 1 ustawy o promocji zatrudnienia jako beneficjenci zlecenia realizacji usług rynku pracy. Następny etap stanowi zawarcie $\mathrm{z}$ organem administracji publicznej zlecającym zadanie umowy o wsparcie realizacji zadania publicznego albo umowy o powierzenie realizacji zadania publicznego (art. 16 ustawy o działalności pożytku publicznego). Umowa ta wymaga formy pisemnej ad solemnitatem i zawierana jest na czas wykonania określonego zadania albo na czas określony nie dłuższy niż 5 lat. Organ administracji publicznej zlecający zadanie ma prawo kontrolować i oceniać realizację zadania, w szczególności pod względem prawidłowości wykorzystania środków publicznych otrzymanych na realizację zadania, czy prowadzenia dokumentacji określonej w przepisach prawa i postanowieniach umowy (art. 17). Szczegółowe dokumenty związane ze zlecaniem zadań publicznych w tym trybie określa rozporządzenie Ministra Pracy i Polityki Społecznej z dnia 27 grudnia 2005 r. w sprawie wzoru oferty realizacji zadania publicznego, ramowego wzoru umowy o wykonanie zadania publicznego i wzoru sprawozdania z wykonania tego zadania $^{48}$. Powstaje pytanie o charakter prawny tej umowy. Zgodnie z art. 16 ustawy podmiot przyjmujący zadanie do realizacji zobowiązuje się do wykonania zadania publicznego na zasadach i w zakresie wskazanym

48 Dz.U. Nr 264, poz. 2207. 
w umowie, a organ administracji zobowiązuje się do przekazania dotacji na realizację tegoż zadania.

W świetle poczynionych poprzednio w odniesieniu do umowy administracyjnej ustaleń, możemy stwierdzić, że także i w tym przypadku występują cechy dla niej właściwe ${ }^{49}$ - zawsze jednym z podmiotów jest podmiot publiczny - starosta, marszałek województwa, zaś przedmiotem umowy jest realizacja zadania publicznego. Umowa ta posiada także inne cechy umowy administracyjnej ${ }^{50}$. Będzie to w szczególności: względna swoboda zawarcia umowy przez strony, która doznaje istotnych ograniczeń poprzez konkurencyjno-eliminacyjny sposób wyboru kontrahenta ${ }^{51}$ (por. art. 13-15 ustawy o działalności pożytku publicznego), określenie warunków zawieranej umowy (ramowy wzór umowy o wykonanie zadania określony przez powołane rozporządzenie), a także określony sposób i zasady sprawowania nadzoru i kontroli nad realizacją powierzonych zadań publicznych ${ }^{52}$ (art. 17 ustawy o działalności pożytku publicznego). W literaturze prawa administracyjnego wskazuje się ponadto, że umowa administracyjna pozwala na wprowadzenie środków ochrony prawnej, znanych prawu cywilnemu, poprzez odpowiednie stosowanie tych przepisó $\mathrm{w}^{53}$ - potwierdzeniem tego może być postanowienie z $\S 17$ wzoru ramowego umowy o wykonanie zadania, w świetle którego w zakresie nieuregulowanym umową stosuje się przepisy ustawy z dnia 23 kwietnia 1964 r. Kodeks cywilny. Opowiadając się zatem za administracyjnoprawnym charakterem

49 Inaczej: D. KuJowsKi, op. cit., s. 282-286. Konkretnie Autor opowiada się za cywilnoprawnym charakterem umów podobnych do tych, wymienionych w przyp. 6 - umowy uregulowane w art. 40 ust. 2, 41 ust. 9, 42, 46, 47 i 53 ustawy o promocji zatrudnienia.

50 Wynika to $\mathrm{z}$ faktu, iż tak samo jak w przypadku istnienia ogólnej kategorii pojęciowej - umowa cywilna, zawierającej poszczególne kategorie umów nazwanych i nienazwanych, tak też w przypadku umowy administracyjnej jest to ogólne określenie, obejmujące wiele rodzajów umów tego typu w zależności od ich przedmiotu B. Dolnicki, R. Cybulska, op. cit., s. 463.
51 A. Panasiuk, op. cit., s. 30, J. Lemańska, op. cit., s. 425.
52 A. Panasiuk, op. cit., s. 30.
53 B. Dolnicki, R. Cybulska, op. cit., s. 464-465. 
tej umowy należy jeszcze raz podkreślić, iż podmiot administracji (marszałek województwa, starosta) zajmuje uprzywilejowaną pozycje w porównaniu z podmiotem prawa prywatnego, co daje mu możliwość kreowania sytuacji prawnej strony wykonującej na mocy umowy zadania administracji publicznej ${ }^{54}$. Wskazywać na to może na przykład art. 24 ust. 2 ustawy o promocji zatrudnienia, w świetle którego zlecanie wykonywania usług rynku pracy lub usług i instrumentów rynku pracy odbywa się przy uwzględnieniu sposobu ich realizacji zgodnie ze standardami usług rynku pracy ${ }^{55}$. Marszałek województwa lub starosta zlecają realizację usług lub instrumentów rynku pracy tylko takiemu podmiotowi, który daje należytą gwarancję ich realizacji zgodnie ze standardami usług rynku pracy.

Powyższe ustalenia można podsumować więc stwierdzeniem, że w przypadkach, gdy stroną zawartej z marszałkiem lub starostą umowy o realizację usług rynku pracy (zlecenie usługi lub usługi i instrumentu rynku pracy) jest jeden z podmiotów, o których mowa w art. 24 ust. 1 należy uznać, że mamy do czynienia z umową administracyjną jeśli jest to podmiot prywatny. Natomiast w przypadku, gdy drugą stroną jest podmiot reprezentujący sferę administracji publicznej, jak np. jednostka samorządu terytorialnego, mamy do czynienia z porozumieniem administracyjnym ${ }^{56}$.

Jeśli chodzi natomiast o regulację ustawy Prawo zamówień publicznych w kwestii zlecania usług lub usług i instrumentów rynku pracy, to jego podstawą prawną jest zasadniczo umowa zawierana zgodnie z art. 139 i nast. tej ustawy. Mają do niej zastosowanie przepisy Kodeksu cywilnego, chyba że przepisy ustawy Prawo zamówień publicznych stanowią inaczej. Wydaje się, że także i w tym przypadku

${ }^{54}$ Por. na temat uprzywilejowanej pozycji podmiotu administracji - B. DoLNICKI, R. Cybulska, op. cit., s. 465.

${ }^{55}$ Określa je rozporządzenie Ministra Pracy i Polityki Społecznej z dnia 14 września 2010 r. w sprawie standardów i warunków prowadzenia usług rynku pracy, Dz.U. Nr 177, poz. 1193.

56 Według przeważającego poglądu administratywistów, z porozumieniem administracyjnym mamy do czynienia, gdy obie jego strony są podmiotami publicznymi, tak np. J. LEMAŃSKA, op. cit., s. 425. 
decydujące znaczenie dla określenia prawnego charakteru tej umowy będzie mieć jej przedmiot, a zatem realizacja zadania publicznego i co jest z tym ściśle związane - charakterystyczny podmiot dysponujący tymi zadaniami, czyli podmiot administrujący (marszałek województwa, starosta). O tym, czy będzie to umowa administracyjna, czy porozumienie decydować będzie charakter podmiotu przyjmującego zadanie publiczne do realizacji.

Warto jeszcze zwrócić uwagę na art. 4 pkt 8, w świetle którego przepisy ustawy Prawo zamówień publicznych nie mają zastosowania do zamówień i konkursów, których wartość nie przekracza wyrażonej w złotych równowartości kwoty 14000 euro. Wydaje się więc, że jeśli równowartość zlecanej usługi lub instrumentu rynku pracy nie przekracza tej kwoty, zastosowanie znajdą ogólne zasady zawierania umowy w drodze przetargu określone w Kodeksie cywilnym. W obecnym stanie prawnym treść i forma umowy zawieranej w ostatnim wskazanym przypadku nie jest przez ustawodawcę uregulowana. Powstaje pytanie - czy w drodze analogii należy przyjąć, że umowa ta ma w szczególności charakter terminowy i powinna zostać zawarta w formie pisemnej ad solemnitatem? Kwestia ta wymagałaby interwencji ustawodawcy.

Poczynione uwagi należy uzupełnić o stwierdzenie, że samo pojęcie zlecania łączyć się może ze wspomnianym wcześniej procesem prywatyzacji zadań publicznych - polega na zlecaniu zadań jednostkom nienależącym do sektora publicznego i wiąże się z finansowaniem lub dofinansowaniem ich działalności ${ }^{57}$. W ustawie o promocji zatrudnienia występuje także pojęcie zlecenia jako umowy cywilnoprawnej, stanowiącej podstawę zatrudnienia ${ }^{58}$.

Kończąc trzeba zauważyć problem, którego rozwiązania podejmują się dotychczas jedynie przedstawiciele doktryny prawa administracyjnego, dotyczący rozwiązywania sporów zaistniałych na gruncie umów administracyjnych. Według jednej z propozycji, spory między podmiotem prywatnym realizującym zadanie a odbiorcą jego świadczeń realizuje administracja w ramach sprawowanego nadzoru, co nie wy-

57 M. Stahl (red.), op. cit., s. 216 i 217.

${ }^{58}$ Np. art. 2 ust. 1 pkt 11. 
klucza możliwości dochodzenia roszczeń przed sądem administracyjnym od samego podmiotu publicznego za niewłaściwe sprawowanie nadzoru $^{59}$. W konsekwencji według prezentowanego poglądu, merytoryczne spory rozstrzygałby sąd administracyjny, natomiast te związane z niewykonaniem bądź niewłaściwym wykonaniem umowy sąd powszechny $^{60}$. Jest jednak watpliwe, czy te same zasady mogłyby dotyczyć rozstrzygania sporów między stronami umowy administracyjnej. Należy bowiem wyrazić obawę, że przedstawione kryterium decydujące o właściwości drogi sądowej jest nieostre i w praktyce trudno będzie precyzyjnie określić organ właściwy do rozstrzygnięcia sporu. Często bowiem dochodzić może do sytuacji, gdy spór merytoryczny można zakwalifikować jako niewłaściwe wykonanie umowy. Ponadto, przedstawiona powyżej metoda rozstrzygania ewentualnych sporów może zostać zakwestionowana $\mathrm{z}$ uwagi na nierównorzędną pozycję stron umowy administracyjnej. Uprzywilejowanie podmiotu publicznego wyrażające się chociażby w kształtowaniu treści umowy w sposób zapewniający realizację interesu publicznego, możliwości dodawania określonych postanowień do umowy, określeniu trybu stosowania przez ten podmiot kontroli realizacji umowy, to elementy głęboko ingerujące w cywilnoprawną zasadę swobody umów. Zasadniczo przemawiają one przeciwko możliwości rozstrzygania sporów powstałych na tle niewykonania bądź niewłaściwego wykonania umowy administracyjnej przez sądy powszechne i za uznaniem właściwości sądów administracyjnych ${ }^{61}$.

Pozostaje jeszcze kwestia ewentualnych sporów dotyczących ustalenia zgodności z prawem treści zawartej umowy administracyjnej, gdyż poprzednie rozważania dotyczyły tylko przypadku jej niewykonywa-

59 J. LEMAŃSKA, op. cit., s. 426.

60 Tamże.

${ }^{61}$ Przepisem procesowym, który mógłby stanowić podstawę skargi jest, moim zdaniem, art. $3 \S 2$ pkt 8 ustawy z dnia 30 sierpnia 2002 r. Prawo o postępowaniu przed sądami administracyjnymi (Dz. U. nr 153, poz. 1270); podobnie: D. KIJOwsKi, op. cit., s. 298. Por. Tenże Problematyka regulacji prawnej stosowania form alternatywnych wobec aktu administracyjnego, [w:] Koncepcja systemu prawa administracyjnego, cit., s. 433. 
nia. Sądy administracyjne nie są bowiem powołane do wydawania merytorycznych rozstrzygnięć spraw administracyjnych, ale do orzekania o legalności aktów i czynności administracji publicznej ${ }^{62}$. Wydaje się, że w rozpatrywanym przypadku umowę administracyjną można by uznać za „,czynność z zakresu administracji publicznej dotyczącą uprawnień lub obowiązków wynikających z przepisów prawa" (art. 3 $\S 2$ pkt 4 poppsa). Przy czym z przytoczonego przepisu wynika tylko, że chodzi o czynności dotyczące uprawnień wynikających z przepisów prawa - czyli w analizowanej sytuacji - uprawnienie organu administracji do samego zawarcia umowy administracyjnej. Powstaje zatem wątpliwość, czy sąd administracyjny na podstawie tego przepisu może badać zgodność z prawem treści umowy. W literaturze prawa administracyjnego wyrażono pogląd, zgodnie z którym sąd administracyjny rozpoznając skargę na bezczynność (art. $3 \S 2$ pkt 8 poppsa - gdy podmiot publiczny nie wykonuje umowy), będzie zmuszony jako zagadnienie wstępne rozstrzygnąć, czy owa umowa wywołuje skutki prawne i dokonać oceny jej treści ${ }^{63}$. Ostatecznym rozwiązaniem przedstawionego problemu wydają się być reguły kolizyjne - jeżeli w konkretnej sprawie sąd administracyjny uzna się za niewłaściwy, sprawę tę będzie musiał rozstrzygnąć sąd powszechny (art. 1991 Kodeksu postępowania cywilnego ${ }^{64}$ ). Jeżeli natomiast sąd powszechny jako pierwszy uzna się za niewłaściwy, sprawę musi rozstrzygnąć sąd administracyjny (art. 58 $\S 4$ poppsa).

Dążąc do podsumowania poczynionych dotychczas uwag należy zaznaczyć, że celem niniejszego opracowania nie było zajęcie ostatecznego stanowiska w kwestii metody, za pomocą której ma przebiegać realizacja zadań publicznych na rynku pracy. Jest to zadanie legislatora. Jednakowoż wydaje się, że publiczny charakter realizowanych na rynku pracy zadań, wymaga zagwarantowania ich realizacji w sposób możliwie najbardziej efektywny, co powinno znaleźć odzwiercie-

${ }^{62}$ Por. art. $3 \S 2$ ustawy z dnia 30 sierpnia 2002 r. Prawo o postępowaniu przed sądami administracyjnymi.

63 D. KuJowsKi, op. cit., s. 298.

${ }^{64}$ Ustawa z dnia 17 listopada 1964 r., Dz.U. Nr 43, poz. 296 ze zm. 
dlenie w odpowiednich formach prawnych działań, podejmowanych przez podmioty administrujące. Przedstawione powyżej rozważania pozwalają jednak wyrazić przekonanie, iż ustawa o promocji zatrudnienia w obecnym kształcie poniekąd oddala od podejmowania skutecznych działań na rynku pracy, powodując konieczność uprzedniego określenia ich metod, które powinny przecież być jasno sformułowane przez ustawodawcę. Jak usiłowano to zasygnalizować powyżej, nie jest obojętne czy realizacja zadania publicznego odbywa się za pomocą metod publicznoprawnych czy prywatnoprawnych. Każda z nich inaczej kształtuje bowiem status prawny podmiotów je wykonujących, a w konsekwencji wpływa na jakość i sposób świadczenia usług lub instrumentów na rynku pracy. Zgodzić się trzeba z ustawodawcą, że różnorodne problemy na rynku pracy wymagają podejmowania zróżnicowanych środków zaradczych. Warto jednak przy ich konstruowaniu pamiętać o podstawowych zasadach techniki prawodawczej, które w szczególności nakazują, by w danym akcie prawnym posługiwać się określonym pojęciem w jednym, ściśle oznaczonym kontekście ${ }^{65}$. Jak wynika z powyższych wywodów zasada ta została przez ustawodawcę naruszona i należy się spodziewać, że będzie to istotnie wpływać na funkcjonowanie całego rynku pracy.

${ }^{65}$ § 10 rozporządzenia Prezesa Rady Ministrów z dnia 20 czerwca 2002 r. w sprawie „Zasad techniki prawodawczej”, Dz.U. Nr 100, poz. 908 - „Do oznaczenia jednakowych pojęć używa się jednakowych określeń, a różnych pojęć nie oznacza się tymi samymi określeniami”. 


\author{
The Agreements, Contracts and Commissioning \\ of Labour Market Services or Instruments on \\ the Basis of the Employment Promotion and Labour \\ Market Institution ACt - A FeW Comments DE LEGE FERENDA.
}

\title{
Summary
}

The main reason for this article is legal language inconsistency occurred in The Employment Promotion and Labour Institution Act of 20 April 2004. In connection with this statute there are reasonable doubt regarding legal nature of agreements, contracts and commissions made on its ground. The Act is abounded with various and ambiguous designations for legal action brought by labour market entities and therefore may cause serious problems in the process of application of the law. The author is of the opinion that solving of this issue may have practical importance for the state and local administration in execution of labour market assignments. 
